\title{
Antalya Demre ilçesinde faaliyet gösteren seraların yapısal özellikleri üzerine bir araştırma
}

\section{A research on the structural properties of greenhouses in Demre district of Antalya}

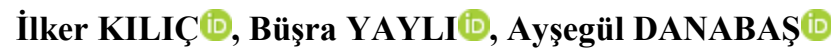 \\ Bursa Uludağ Üniversitesi, Ziraat Fakültesi, Biyosistem Mühendisliği Bölümü, 16059, Bursa, Türkiye \\ Sorumlu yazar (Corresponding author): İ. Kılıç, e-posta (e-mail): ikilic@uludag.edu.tr \\ Yazar(lar) e-posta (Author e-mail): busrayayli@uludag.edu.tr, aysgldnbs@gmail.com
}

\section{MAKALE BİLGİSİ}

Alınış tarihi 18 Şubat 2020

Düzeltilme tarihi 16 Mayıs 2020

Kabul tarihi 20 Mayis 2020

\section{Anahtar Kelimeler:}

Antalya

Sera

Konstrüksiyon

Sera boyutları

Yapı elemanları

\section{ÖZ}

Bu çalışmada, Antalya ili Demre ilçesinde faaliyet gösteren seraların işletme, yapısal ve teknik özelliklerinin belirlenmesi amaçlanmıştır. Bu amaçla, bölgede 50 adet serada, işletme sahipleriyle bire bir yapılan anket çalışması ile veriler elde edilmiştir. Yapılan anket sonuçlarına göre Demre ilçesinde incelenen 50 adet işletmenin \%64'ü sera ve \%36'sı yüksek tünel seralardan oluşmaktadır. Sera işletme sahiplerinin \%70'inin eğitim düzeyi ilköğretim seviyesidir ve incelenen tüm işletmelerde aile işletmeciliği yapılmaktadır. Seraların konstrüksiyon sistemi incelendiğinde tamamının çelik profillerden yapıldığı ve \%78'inin plastik örtü materyali ile kaplandığ gözlemlenmiştir. İşletmelerin boyutsal özelliklerinin uzunluk ve yüksekliklerinin literatürdeki değerlerle uyumlu olduğu fakat sera genişliğinin literatürdeki değerlerden yüksek olduğu ortaya konulmuştur.

\section{ARTICLE INFO}

Received 18 February 2020

Received in revised form 16 May 2020

Accepted 20 May 2020

\section{Keywords:}

Antalya

Greenhouse

Construction

Greenhouse dimensions

Construction elements

\begin{abstract}
In this paper, it is aimed to determine the current status of the structural properties of greenhouses operating in Demre district of Antalya province. For this purpose, data were obtained through a one-on-one survey study with operations' owners of 50 greenhouses in the region. According to the survey results, it was determined that of those 50 greenhouses examined in Demre district $64 \%$ are greenhouse and $36 \%$ are high tunnel greenhouse. The education level of $70 \%$ of greenhouse owners is the primary level, and family management is carried out in all the operations. When the construction system of the greenhouses is examined, it is observed that all of them are made of steel profile, and $78 \%$ of them are made of plastic cover material. It has been demonstrated that the length and height of the dimensional properties of the greenhouses are compatible with the values in the literature. On the other hand, greenhouse width is wider than the values cited in the literature.
\end{abstract}

\section{Giriş}

Türkiye'de nüfusun artışıla birlikte tarımsal ürün tüketim miktarında artış, çeşitli nedenlerle tarımsal arazilerin küçülmesi, kırsal alanlardan kente göçlerin artması gibi sebepler ile seracılık daha önemli bir noktaya gelmiştir. Seralar; iklimsel çevre koşullarına tümüyle veya kısmen bağlı kalmadan, sıcaklık, 1şık ve nem gibi faktörlerin kontrol altında tutulmasıyla bütün yıl boyunca çeşitli kültür bitkileriyle, bunların tohum, fide ve fidanlarını üretmek, bitkileri korumak ve sergilemek amacıyla, cam, plastik vb. 1şı geçirebilen malzeme ile kaplanarak değişik şekillerde yapılan bitkisel üretim yapılarıdır (Öneş 1986; Yağanoğlu ve Örüng 1997; Yüksel 2000; Genç ve ark. 2010).
Örtüaltı tarımında kullanılan yapılar alçak plastik tüneller, yüksek plastik tüneller ve seralar olmak üzere üç grupta incelenmektedir. Fakat bitki yetiştirilebilmesi için çevre koşullarının olumsuz etkilerini kısmen ortadan kaldıran alçak ve yüksek tüneller, sera olarak nitelendirilmemektedir (Topçuoğlu 2013).

Günümüz Türkiye'sinde 61512 hektar olan örtüaltı yetiştiricilik alanlarının 8074 hektarı cam ve 27866 hektarı plastik örtülü seralardır. Halen kullanılan cam seraların oranı $\% 22$, plastik sera oranı ise \%78'dir. Örtüaltı seracıllı̆̆ı \%84'ü Akdeniz Bölgesi'nde yapılmaktadır (Baytorun 2016). 
Türkiye'de seracılığın son 10 yılda gelişmesiyle birlikte işletme büyüklükleri taban alanı olarak ortalama 2 dekardan 4 dekara kadar çıkmıştır Toplam sera varlığı olarak üretim alanı ise yaklaşık 790 bin dekarlık bir seviyeye ulaşmıştır. Niteliklerine göre cam sera 75495 dekar, plastik sera 378670 dekar, yüksek sera 111038 dekar ve alçak tünel 224400 dekarlık alanı kapsamaktadır (Tarım ve Orman Bakanlığı 2019). Antalya ili hem Akdeniz bölgesinin hem de Türkiye'nin örtüaltı yetiştiriciliğinde ilk sırada gelmektedir (Çizelge 1). Hem ülke genelinde hem de Akdeniz bölgesinde en fazla üretim yapan şehir \%48'lik oran (3.8 milyon ton) ile Antalya'dır. Ülkemizin seracılıkta önde gelen diğer illeri sırası ile Mersin (\%16), Adana (\%13) ve Muğla (\%9)'dır (Tarım ve Orman Bakanlığı 2019). $\mathrm{Bu}$ durum Akdeniz bölgesinin seracılık açısından önemli bir merkez konumunda olduğunu göstermektedir.

Çizelge 1. Bazı illerin örtüaltı alanları (TUIKK 2019).

Table 1. Areas of greenhouses by some provinces (TUiK 2019).

\begin{tabular}{cc}
\hline Şehir & Örtüaltı tarım alanı $(\mathrm{da})$ \\
\hline Türkiye & 789.604 \\
Antalya & 286.522 \\
Mersin & 201.060 \\
Adana & 160.493 \\
Muğla & 39.048 \\
İzmir & 14.016 \\
Aydın & 12.717 \\
Hatay & 11.456 \\
Burdur & 9.843 \\
Isparta & 4.942 \\
Amasya & 4.881 \\
\hline
\end{tabular}

Günümüzde, gerek birim alandan alınan ürün miktarında artış gerekse sera içerisindeki sıcaklık koşullarının kontrol altında tutulması, seraları modern üretim alanları haline getirmiştir. Türkiye'nin Akdeniz ve Ege Bölgesi'ndeki sera alanları iç tüketim potansiyelini karşılamakta her ne kadar yeterli olsa da tarım alanlarının gerek yerleşim olarak gerekse sanayi alanı veya turizm alanı olarak kullanılmasından dolayı gün geçtikçe azalmaktadır (Saltuk ve ark. 2019).

Kuruldukları bölgenin mikroklima koşullarına, toprak yapısına, yetiştirilen ürünlere ve maddi imkânlarına göre seralar yapısal özellikleri açısından birbirlerinden farklılık göstermektedir. Sera yapı elemanları temel, konstrüksiyon elemanları ve çatı olarak sınıflandırılabilmektedir ve bu elemanların seçilmesinde ve inşasında bölgenin iklim durumu, yetiştirilmek istenen bitkinin türü, seracılık işletmesinin büyüklüğü ve işletmenin çeşidi dikkate alınmaktadır (Genç Ziraat 2019).

Seralardan kaliteli yüksek verimin elde edilebilmesi için; iç ortam sıcaklıklarının kontrol edilmesi oldukça önemlidir. Örneğin; sera diş sıcaklık değerleri $0-12^{\circ} \mathrm{C}$ arasında ise sera içinde 1 sıtma, $12-22^{\circ} \mathrm{C}$ arasında ise sera içi doğal havalandırma, $22-27^{\circ} \mathrm{C}$ arasında ise mekanik havalandırma ve/veya soğutma yapılmalıdır (Von Zabeltitz 2011).

Olumsuz çevre koşullarında daha çok cam sera yaygınlık gösterirken, 1lıman iklimlerde örtü materyali olarak plastik örtü tercih edilmektedir. Fakat ülkemizde plastik örtü materyalleri daha ekonomik olduğundan dolayı kullanımı daha yaygındır ve genelde polietilen malzeme kullanılmaktadır. Ülke genelindeki seraların \%10'u cam sera, \%48'i plastik sera, \%14'ü yüksek tünel ve \%28'i ise alçak tüneldir (TUIK 2019).
Seralarda yeterli 1şığın gelmesi ve azami ısınmanın sağlanabilmesi için seraların kuruluş yönleri önemlidir. Bu nedenle seraların uzun ekseninin güneş ışınlarında en fazla oranda yararlanabilmek için güneş 1şı̆̆ yetersiz olan yerlerde doğu-batı yönünde ve güneş 1şı̆̆ının fazla olduğu bölgelerde ise kuzey-güney doğrultusunda kurulmalı; bitki sıralarının ise birbirlerine gölge oluşturmayacak şekilde kuzey-güney yönünde yerleştirilmesi daha yararlı olmaktadır (TÜRKTOP 2012; Olgun 2016).

Sera örtü materyallerinde ve iç ortamda yoğunlaşma olmaması için iç ortam hava sıcaklığının ve bağıl nem oranının düşük seviyede tutulması ve ortam havasında $\mathrm{CO}_{2}$ konsantrasyonunun üretimi yapılan ürünler için belirli bir düzeyde tutulabilmesi amacıyla havalandırma yapılmaktadır (Güllüler 2007). Havalandırma, seralarda bulunan havalandırma açıklıkları ile doğal yolla yapılabildiği gibi, doğal havalandırmanın yetersiz olduğu bölgelerde mekanik olarak da gerçekleştirilebilmektedir.

Doğal havalandırma yönteminde havalandırma açıklıkları genellikle seraların yan duvarlarında ya da çatılarında bulunan pencereler şeklinde uygulanmaktadır. Fakat doğal havalandırma için çatı pencerelerini kullanmak daha etkili bir yöntemdir. Soğuk bölgelerde kurulu olan seralarda çatı pencereleri daha küçüktür. Çatı pencerelerinin açılıp kapanabilmeleri için farklı tipte sistemler kullanıldığı gibi en az yatay yüzey ile $15^{\circ}$ açı yapacak şekilde kurulmalıdır. Yeterli bir havalandırma için çatı pencerelerinin toplam alanı, seranın sahip olduğu taban alanın \%16-20'si kadar olması önerilmektedir (Genç 1981; Yüksel ve Yüksel 2012). Yan duvar pencerelerinin toplam alanı ise çatı pencerelerin 2/3'ü kadar olmalıdır. İçeriye ve dişarıya doğru açılıp kapanabilmekle birlikte düşeyle $70^{\circ}$ lik açı yapacak şekilde açılmalıdır (Yüksel ve Yüksel 2012).

Seralarda mekanik havalandırma yöntemleri olarak genellikle emici, basıc1 ve kombine tipte havalandırma sistemleri kullanılmaktadır. Emici tip havalandırma sistemleri daha çok plastik seralarda kullanılırken, basıcı tip havalandırma sistemleri ise daha çok fide yetiştirme seralarında ya da bireysel seralarda kullanılmaktadır (Olgun 2016).

Bu çalışmada Antalya'nın Demre ilçesinde bulunan 50 adet seracılık işletme sahipleri ile yüz yüze anketler yapılmıştır. Anketler sonucunda bölgedeki seraların işletme, yapısal ve teknik özellikleri belirlenmiştir ve belirlenen sorunlara yönelik öneriler sunulmuştur.

\section{Materyal ve Yöntem}

Bu çalışma, Antalya ili Demre ilçesinde 2018 yılının Haziran-Aralık aylarında yürütülmüştür. Anket çalışması yapılan Demre ilçesi haritası Şekil 1'de verilmiştir (Google Haritalar 2019). Demre ilçesi Antalya'nın batısında Finike ve Kaş ilçeleri arasında yer almaktadır. İlçe halkının geçim kaynağı çoğunlukla tarımdır. Demre ilçesinde toplam 20000 dekarlık kapalı sera alanı bulunmaktadır. Demre ilçesinin özellikle yurt içinde turfanda sebze konusunda sahip olduğu pazar büyüktür ve örtüaltı sebzeciliğe ait bilgiler Çizelge 2'de verilmiştir (T.C. Demre Kaymakamlığ 2019).

Çalışmanın materyali için Demre ilçesinde sera yetiştiriciliği yapan ve bölgeyi temsil eder nitelikte 50 adet işletme seçilmiştir. İşletme sahipleri ile yüz yüze yapılan anket çalışmaları sonucunda işletmelerin işletme, yapısal ve teknik özellikleri belirlenmiştir. Anket değerlendirmelerinde belirlenen sorunlara yönelik çözüm önerileri sunulmuştur. 


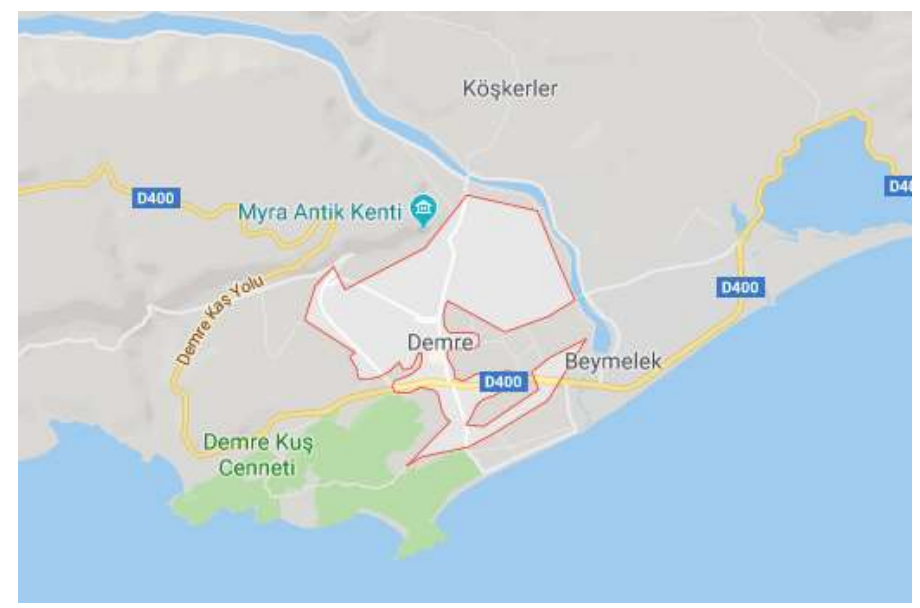

Şekil 1. Antalya/Demre ilçesi konumu (Google Haritalar 2019).

Figure 1. Antalya/Demre district location (Google Haritalar 2019).

Çizelge 2. Demre ilçesine ait örtüaltı sebze yıllık üretim değerleri.

Table 2. Annual production values of greenhouse vegetables in Demre district.

\begin{tabular}{cccr}
\hline Ürün Adı & Ekili/Dikili Alan (da) & Dekara Verim (ton y1l ${ }^{-1}$ ) & Y1llk Toplam Üretim (ton) \\
\hline Domates & 12000 & 17.5 & 210000 \\
Biber & 7000 & 14 & 100500 \\
Hiyar & 625 & 20 & 12500 \\
Patlican & 35 & 16 & 560 \\
Kabak & 340 & 16 & 5440 \\
Toplam & 20000 & & 329000 \\
\hline
\end{tabular}

\section{Bulgular ve Tartışma}

\subsection{Incelenen işletmelere ve işletme sahiplerine ilişkin genel bilgiler}

Çalışmanın arazi çalışmalarında işletme sahipleri ile yüz yüze yapılan anketler ile elde edilen genel bilgiler Çizelge 3 'de verilmiştir. Antalya ili Demre ilçesinde faaliyet gösteren sera işletmeleri içerisinde anket yapılan işletme sahiplerinin \%70'inin ilkokul, \%24'ünün ortaokul ve \%6'sının lise mezunu olduğu belirlenmiştir. Türkay ve ark. (2006) tarafından Anamur ilçesinde bulunan sera sahipleri ile yaptıkları anket çalışmasında, incelenen işletme sahiplerinin \%48'inin ilkokul mezunu olduğunu ve bu oranın en yüksek değer olduğunu belirtmișlerdir. Tüzel ve ark. (2010) ise Antalya ili Serik ilçesinde yaptıkları anket çalışmasında incelenen geleneksel seraların sahiplerinin $\% 90$ oranında ilkokul mezunu olduklarını bulmuşlardır. Çalışmada yapılan arazi incelemelerinde geçimini tarımdan sağlayan üreticilerin büyük bir kısmının, ilkokul mezunu olduğu gözlemlenmiştir. İşletme sahiplerinin genellikle ilkokul mezunu olması ve geleneksel olarak seracılık faaliyetlerini gerçekleştirmelerinden dolayı bir önceki nesilden nasıl öğrenildiyse seracılık faaliyetlerine o şekilde devam edilmektedir. Eğitim seviyesinin düşüklüğü, yeniliğe kapalı olmalarına neden olmakla birlikte modern ve son tekniklerden haberdar olsalar dahi bunları seralarına uygulamakta çekinmektedirler. $\mathrm{Bu}$ durum gelişen sera teknolojisinin uygulamaya yansımamasına, işgücünün azalıp birim alandan verimliliğin artmasına engel olmaktadır.

Çalışmada anket yapılan işletmelerin tümünün $(\% 100)$ aile işletmesi olarak üretim yaptıkları belirlenmiştir. Benzer şekilde incelenen işletmelerin $\% 98$ 'inin projesiz yapıldığ 1 ve $\% 2$ 'sinin projeli olarak inşa edildiği belirlenmiştir. Bu durumda incelenen işletmelerin sadece biri sera kurulumu konusunda bilgi sahibi profesyonel kişilerin uzmanlıklarına başvurulduğu söylenebilir. $\mathrm{Bu}$ nedenle sera içi iklimsel çevre koşullarının optimum seviyelerde tutulması projeli olarak yapılan serada daha kolay ve maliyetsiz olacağı düşünülebilir. Projesiz yapılan seraların \%52'sinde sera kurulurken bazı işletmelerin işletme sahibinin kendi fikri veya önceki deneyimlerine bağlı olarak inşa edildiği belirlenirken \%48'inde ise çevrede kurulu bulunan seraların örnek alınarak inşa edildiği belirlenmiştir.

Çalışmada incelenen seracılık işletmelerinin tamamının aile işletmesi olmasına rağmen \%14'ünün işçi çalıştırdığ 1 belirlenmiştir. İncelenen seraların \%86'sında ise aile bireyleri çalışmaktadır. İşçi çalıştıran işletmelerde çoğunlukla bir işçi çalıştırıldığı, bir işletmede 2 işçi ve bir işletmede de 3 işçi çalıştırıldığg tespit edilmiştir.

İncelenen seralarda elde edilen tarımsal ürünlerin pazarlanmasında üreticiler farklı seçenekleri kullandıkları belirlenmiştir. Çalışmada anket yapılan seraların \%50'sinin komisyoncular aracılığıyla yurtdışına, \%42'sinin hem yurtiçine hem de yurtdışına ve sadece $\% 8$ 'sinin yurtiçine farklı pazarlama yöntemleriyle sattıkları görülmüştür. Tüzel ve ark. (2010) yaptıkları çalışmada Serik ilçesinde faaliyet gösteren modern seraların tamamına yakınının ürettikleri ürünleri ihracata gönderildiğini belirlemişlerdir.

Çalışmada incelenen seracılık işletme sahiplerinin $\% 72$ 'sinin 15 yıldan daha fazla bu işle uğraştığı tespit edilmiştir ve \%40'nın aynı serada 15 yıldan daha fazla süredir işletmecilik yaptığ1 görülmüştür. İncelenen seracılık işletmelerinin \%14'ünde işletme sahipleri 5-10 y1l arası ve \%8'inde ise 10-15 yıl arası deneyime sahiptir. Sadece \%6'sının ise bu işe yeni başladıkları tespit edilmiştir. İşletme sahiplerinin seracılıkla uzun yıllar boyunca uğraşması bu iş ile ilgili deneyim sahibi 
olduklarını göstermektedir. Benzer şekilde aynı seranın uzun yıllar boyunca aynı işletme sahibi tarafindan işletilmesi seranın yapısal özelliklerinin daha iyi tanınmasını ve bu durumun üretim verimliliğine olumlu etkisinin olacağı düşünülmektedir. Tüzel ve ark. (2010) çalışmalarında bu çalışma ile benzer şekilde Serik ilçesinde seracılıkla uğraşan geleneksel üreticilerin $\% 50$ 'sinin 15 yıldan fazla süredir seracılıkla uğraştıklarını belirlemişlerdir. Çanakcı ve Akıncı (2007) ve Gale ve ark. (2014) Antalya bölgesinde yaptıkları çalışma da bu bölgede seracılık faaliyetlerinin ikinci ve üçüncü kuşak aile bireyleri tarafından yapıldığını ve işletme sahiplerinin 15 yıldan daha uzun süredir bu işle uğraştıklarını bildirmektedirler.

\subsection{Incelenen seraların boyutsal özellikleri}

Çalışmada incelenen seraların boyutsal özellikleri Çizelge 4'te verilmiştir. İşletmelerin sera boyutları lazermetre yardımıyla ölçülmüştür. Buna göre incelenen seraların genişlikleri 11-80 m, yükseklikleri 1-9 m, uzunlukları 30-150 m ve yan duvar yükseklikleri 2-4 $\mathrm{m}$ arasında değiştiği belirlenmiştir. Çalışmada en sık karşılan genişlik aralığ 21-40 m olup genel olarak ortalama sera genişliği 23.8 m'dir. Ayrıca çatı genişliği kriteri de dikkate alındığın da seraların genişliğinin cam seralarda 9-12 $\mathrm{m}$, plastik seralarda 6-9 m arasında olmalıdır (Yüksel ve Yüksel 2012). Hakgören ve Kürklü (2004), eşlenik çatılı bireysel seralarda sera genişliğinin 3-23 m arasında planlanabilir olduğunu ve 45-50 m'den uzun seraların işçilik maliyetlerini artırması nedeniyle önerilmediğini bildirmektedir. İncelenen seralarda mahya yüksekliğinin \%67 oranın 3 ile $6 \mathrm{~m}$ arasında değişmektedir. Yan duvar yükseklikleri ise \%64 oranıla 2-4 m'dir. Yüksel ve Yüksel (2012) yan duvar yüksekliğinin, seraların 1sı kaybı dikkate alınarak soğuk bölgelerde $210-220 \mathrm{~cm}$, 1lıman bölgelerde 220-250 cm ve sicak bölgelerde 250-300 cm arasında olmasi gerektiğini bildirmişlerdir.

Saltuk (2018) tarafından Mersin ilinde yapılan çalışmada, sera kurulumunda yaşanan bilgi eksikliğinin seraları kötü tasarlanmış tarımsal üretim yapılarına dönüştürdüğünü bildirilmiştir.

Çalışmada anket yapılan seraların uzunluklarının en çok 31-60 m arasında değişmektedir. Buna karşın Yağanoğlu (2013), seraların 1sitma ve havalandırma gereksinimleri açısından sera uzunluğunun 50-60 m arasında olmasının uygun olacağını belirtmiştir.

Literatürde yapılan çalışmalar ışı̆̆ında, çalışmada incelenen seraların, toplam genişliklerinin iki adet blok sera dışındaki tekil seralarda önerilen sınır değerlerin üstünde olduğu görülmektedir. Sera uzunluklarının bazı araştırmacıların önerdiği değerlere uygunken, bazı araştırmacıların önerdiği değerlerin ise üstünde olduğu belirlenmiştir. Sera yükseklik ve yan duvar yüksekliklerinin ise literatürde önerilen yükseklik değerleri ile uyum içerisinde olduğu gözlemlenmiştir.

Çizelge 3. İşletmeler ile ilgili genel bilgiler.

Table 3. General information about enterprises.

\begin{tabular}{|c|c|c|c|}
\hline \multirow[b]{2}{*}{ İșletmelere ait genel bilgiler } & \multirow[b]{2}{*}{ Seçenekler } & \multicolumn{2}{|c|}{ İşletme Sayısı } \\
\hline & & Adet & Yüzde (\%) \\
\hline \multirow{4}{*}{ İşletme sahibi eğitim durumu } & İlköğretim & 35 & 70 \\
\hline & Ortaöğretim & 12 & 24 \\
\hline & Lise & 3 & 6 \\
\hline & Üniversite & - & - \\
\hline \multirow{3}{*}{ İşletmenin yapısı } & Aile İşletmesi & 50 & 100 \\
\hline & Ortaklık İşletmesi & - & - \\
\hline & Hibe Destekli İşletme & - & - \\
\hline \multirow{2}{*}{ Proje durumu } & Projeli & 1 & 2 \\
\hline & Projesiz & 49 & 98 \\
\hline \multirow{2}{*}{ İşletmede Çalışan İşşi Durumu } & Evet & 7 & 14 \\
\hline & Hayır & 43 & 86 \\
\hline \multirow{3}{*}{ İşletmede Çalışan işçi Sayısı } & $0-1$ & 5 & 72 \\
\hline & $1.1-2$ & 1 & 14 \\
\hline & $2.1-3$ & 1 & 14 \\
\hline \multirow{3}{*}{ Ürünlerin Pazarlanması } & Yurtiçi & 4 & 8 \\
\hline & Yurtdışı & 25 & 50 \\
\hline & Karma & 21 & 42 \\
\hline \multirow{4}{*}{ Seracılıkla ilgili deneyim } & $1-5 \mathrm{y} 11$ & 3 & 6 \\
\hline & $5-10 \mathrm{y} 11$ & 7 & 14 \\
\hline & $10-15$ y1l & 4 & 8 \\
\hline & $15 \mathrm{y} 11<$ & 36 & 72 \\
\hline \multirow{4}{*}{ Seranın işletilme süresi } & $1-5 \mathrm{y} 11$ & 9 & 18 \\
\hline & $5-10 \mathrm{y} 11$ & 6 & 12 \\
\hline & $10-15$ y1l & 15 & 30 \\
\hline & $15 \mathrm{yll}<$ & 20 & 40 \\
\hline
\end{tabular}


Çizelge 4. İncelenen seraların boyutsal özellikleri.

Table 4. Dimensional properties of the monitored greenhouses.

\begin{tabular}{|c|c|c|c|}
\hline Parametre & Boyutlar & Sera sayısı & Yüzde (\%) \\
\hline \multirow{4}{*}{ Genişlik } & $\leq 20$ & 23 & 46 \\
\hline & $21-40$ & 24 & 48 \\
\hline & $41-60$ & 2 & 4 \\
\hline & $61-80$ & 1 & 2 \\
\hline \multirow{3}{*}{ Yükseklik } & $\leq 3$ & 16 & 32 \\
\hline & $3.1-6$ & 33 & 67 \\
\hline & $6.1-9$ & 1 & 2 \\
\hline \multirow{5}{*}{ Uzunluk } & $\leq 30$ & 1 & 2 \\
\hline & $31-60$ & 23 & 46 \\
\hline & $61-90$ & 21 & 42 \\
\hline & $91-120$ & 4 & 8 \\
\hline & $121-150$ & 1 & 2 \\
\hline \multirow{2}{*}{ Yan Duvar Yüksekliği } & $\leq 2$ & 18 & 36 \\
\hline & $2.1-4$ & 32 & 64 \\
\hline
\end{tabular}

\section{3. İncelenen seraların yapısal özellikleri ile ilgili bilgiler}

Bir seranın yapısal olarak en önemli özelliği seranın yapısal elemanlarının kendi ağırlı̆̆ 1 ile birlikte üzerine etki etme olasılığı bulunan yükleri rijitliğini bozmadan taşıyabilmesidir. İncelenen seralara ait genel yapısal özellikler Çizelge 5'de verilmiştir. Seralarda iskelet malzemesi olarak tek organik madde olan ahşap malzemeden çok eski zamanlardan beri yararlanılmaktadır. Fakat 1990'lı yıllardan beri ahşap sera malzemesi kullanılmamakla birlikte hafif ve dış hava koşullarından çok etkilenmeyen çelik profiller, alüminyum ve alaşımları günümüzde yaygın olarak kullanılmaktadır. İncelenen seraların tamamında konstrüksiyon malzemesi olarak çeşitli boy ve kesitlerde çelik profiller kullanılmıştır.

Seralarda yetiştiricilik türü, yerleşim yerinin iklim koşulları, işletme sahibinin tercihi, işletmenin ekonomik gücü, işletmenin alet ve ekipman olanakları gibi sebeplerle sera tipleri farklılık gösterebilmektedir (Yüksel ve Yüksel 2012). İncelenen seralar, kuruluş şekillerine göre değerlendirildiğinde \%36's1 yüksek tünel ve \%64'ü seradır. Boyacı (2018), Kırşehir'de yapmış olduğu bir çalışmada sera ve yüksek tünel işletmelerinin bulunduğu işletmeleri incelemiştir. İncelediği 10 adet sera işletmesinin \%60'ının ve 15 adet yüksek tünel işletmesinin ise \%20'sinin 0-5 yıl arasında yetiştiricilik yaptığını belirtmiştir. Bunun sebebinin Türkiye'nin güneyinde başlayan ve örtüaltı tarımının yoğun olarak yapıldığı Antalya ilinde üreticilerin çoğunluğu tecrübe sahibi iken Kırşehir ilinde sera ve yüksek tünelde yetiştiricilik tecrübesinde yeni olduklarını belirtmiştir.

Seralarda çatı ve iskeletlerin örtü malzemesi olarak plastik ve cam malzemeler kullanılmaktadır. Plastik örtü malzemesi ekonomik olduğundan dolayı en yaygın kullanılan materyaldir. Plastik örtü malzemesi olarak polietilen plastiklerden UV, IR ve antifog katkılı plastikler uzun ömürlü olmaları nedeniyle üreticiler tarafindan sıklıkla tercih edilmektedir (Saltuk 2005). İncelenen seralarda örtü malzemesi olarak \%78 oranında plastik örtülü seralar kullanılmıştır. Kullanılan plastik materyal incelendiğinde ise $\% 90 \mathrm{UV}+\mathrm{IR}+\mathrm{EVA}$ katkılı polietilen plastik örtünün kullanıldığı belirlenmiştir. Fenkli ve Filiz (2013), Batı Akdeniz bölgesindeki seralarda yaptıkları çalışmada incelenen seraların \%64.6'sının plastik örtü malzemesi kullanılarak inşa edildiğini tespit etmişlerdir.

\section{4. İncelenen işletmelerin yapı elemanları ile ilgili bilgiler}

Seranın yapısal elemanları seranın kurulmak istendiği iklim koşullarına, yetiştirilecek bitkinin türüne, işletme büyüklük ve tipine bağlı olarak önem kazanmaktadır (Arıcı 2003). Seranın çatı örtüsü hafif olsa da temelinin iklim koşullarına karşı dayanıklı olması gerekmektedir. Çatı üzerinde örtü malzemesinin ve merteklerin yüklerini çatı makaslarına ileten aşıklar, seraların tasarımında önemli taşıyıcı yapısal elemanlardır. İncelenen seralarda aşıkların uzunlukları 40'tan az ve 200'den fazla olacak şekilde çeşitli sayılarda inşa edilmiştir. Seralarda en yaygın (\%26 oranında) 41-80 adet aralığında aşıklar bulunmaktadır (Çizelge 6).

Seralarda havalandırma sistemi doğal ve mekanik havalandırma şeklinde uygulanmaktadır. İncelenen 50 adet serada doğal havalandırma, havalandırma açıklıkları ile gerçekleştirilmektedir. Doğal havalandırma sistemlerinde havalandırma işlemi sera yan duvarları ve çatılarında bulunan pencerelerden gerçekleştirilir. İyi bir havalandırma yapılabilmesi için seranın, pencere toplam alanının sera taban alanının \%16-25'i arasında olmas1 gerekir (Kolay 2016). Pencereler, sera iç ortamındaki oksijen dengesi ve $\mathrm{CO}_{2}$ miktarının azalması, fazla 1 sı ve nemin optimum değerlerde tutulmasını sağlamak için gerekli doğal havalandırmayı sağlamaları açısından önemli yapı elemanlarıdır (Fenkli 2012). Çalışmada incelenen seraların havalandırma açıklıklarının eni 0.45-2 m, boyu 0.50-2 $\mathrm{m}$ ve açıklıkları 0.30-2 $\mathrm{m}$ arasında değiştiği gözlemlenmiştir. Pencerelerin boyutları ise en 1-2 m ve boy 0.50-151 m aralarında değişiklik göstermektedir.

Seralarda kapilar iş giriş çıkışını sağlayan, doğal 1şı̆̆ geçiren saydam örtülü yapı elemanıdır. Seralarsa kapıların genişliği 90-180 cm ve yükseklik $200 \mathrm{~cm}$ olmalıdır (Yüksel ve Yüksel 2012). İncelenen seralarda kapıların genişliği 1-3 m ve boyları 1-3 m arasında değişmekte olduğu gözlemlenmiştir.

\subsection{Incelenen işletmelerde seraların bakımı ile ilgili bilgiler}

Seralarda kullanım ömrü ilerledikçe hem sera iç ortamında hem de sera örtü malzemesinde yıpranmalar meydana gelmektedir. Seraları daha uzun ve verimli kullanılabilmesi için düzenli olarak bakım ve onarım çalışmalarının yapılması 
gerekmektedir (Güllüler 2007). Modern seralarda yapılan üretim çok verimli olmaktadır. Bunun yanında seralardaki plastik örtünün bertaraf edilmesi önemli bir sorun olmaktadır ve çevresel etkileri giderek artmaktadır (Atılgan ve ark. 2014). Anket çalışması yapılan seralarda plastik örtü materyali kullanan seralarda örtülerin yenilenme sürelerinin 1-3 yıl arasında değiștiği gözlemlenmiştir (Çizelge 7). İșletmelerin \%76's1 örtü malzemelerini 3 yılda bir yenilemektedirler. Cam örtü materyali kullanan seralarda ise seraların \%55'inin örtü materyallerinin bakımlarının 3 yıldan fazla sürelerle yapıldı belirlenmiştir. İncelenen seralarda işletme sahipleri seraların temizliklerinde farklı yöntemler uygulamakta oldukları gözlemlenmiştir. Seraların \%30'unda sera örtü malzemesi basınçlı su ile yıkanarak temizlenirken, seraların \%70'inde ise işletme sahiplerinin sera örtü malzemelerinin yıkanması için yağmurun yağmasını beklemektedir.

Çizelge 5. İşletmenin yapısal özellikleri ile ilgili bilgiler.

Table 5. Information about the structural features of the enterprises.

\begin{tabular}{cccc}
\hline & & & İşletme Sayıs \\
İşletmelere ait genel bilgiler & Seçenekler & Adet & Yüzde (\%) \\
\cline { 2 - 3 } Sera konstrüksiyon malzemesi & Ahşap & - & - \\
& Çelik & 50 & 100 \\
& Galvanize Demir & - & - \\
& Hava şişirmeli sera & - & - \\
\hline \multirow{2}{*}{ Sera yapısı çeşidi } & Alüminyum & - & - \\
& Alçak Tünel & - & 36 \\
Sera örtü malzemesi & Yüksek Tünel & 18 & 64 \\
& Sera & 32 & 16 \\
Serada kullanılan plastik örtü & Cam & 8 & 78 \\
malzemesi & Plastik & 39 & 6 \\
\hline & Cam-Plastik & 3 & 5 \\
& Polietilen & 2 & 2 \\
\end{tabular}

Çizelge 6. İncelenen seraların yapı elemanlarının boyutsal özellikleri.

Table 6. Dimensional properties of the structural elements of the greenhouses monitored.

\begin{tabular}{|c|c|c|c|c|}
\hline Yap1 Elemanı & \multicolumn{2}{|c|}{ Seçenekler } & Sera sayısı & Yüzde (\%) \\
\hline & \multicolumn{2}{|c|}{$\leq 40$} & 1 & 2 \\
\hline & \multicolumn{2}{|c|}{$41-80$} & 13 & 26 \\
\hline 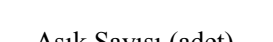 & \multicolumn{2}{|c|}{$81-120$} & 12 & 24 \\
\hline Aşık Sayısı (adet) & \multicolumn{2}{|c|}{$121-160$} & 7 & 14 \\
\hline & \multicolumn{2}{|c|}{$161-200$} & 6 & 12 \\
\hline & \multicolumn{2}{|c|}{$200<$} & 11 & 22 \\
\hline \multirow{5}{*}{ Pencere } & \multirow{2}{*}{ En (m) } & $\leq 1$ & 4 & 8 \\
\hline & & $1.1-2$ & 46 & 92 \\
\hline & \multirow{3}{*}{ Boy $(\mathrm{m})$} & $\leq 50$ & 29 & 58 \\
\hline & & $51-100$ & 20 & 40 \\
\hline & & $100-151$ & 1 & 2 \\
\hline \multirow{6}{*}{ Kap1 } & \multirow{3}{*}{ Genişlik (m) } & $\leq 1$ & 7 & 14 \\
\hline & & $1.1-2$ & 20 & 40 \\
\hline & & $2.1-3$ & 23 & 46 \\
\hline & \multirow{3}{*}{ Boy $(m)$} & $\leq 1$ & - & - \\
\hline & & $1.1-2$ & 25 & 50 \\
\hline & & $2.1-3$ & 25 & 50 \\
\hline \multirow{6}{*}{ Havalandırma Açıklığı } & \multirow{2}{*}{ En (m) } & $\leq 1$ & 16 & 94 \\
\hline & & $1.1-2$ & 1 & 6 \\
\hline & \multirow{2}{*}{ Boy (m) } & $\leq 1$ & 9 & 60 \\
\hline & & $1.1-2$ & 6 & 40 \\
\hline & \multirow{2}{*}{ Açıklık (m) } & $\leq 1$ & 23 & 100 \\
\hline & & $1.1-2$ & 0 & 0 \\
\hline
\end{tabular}


Çizelge 7. Yapı elemanlarının yenilenmesi ve bakımı ile ilgili bilgiler.

Table 7. Information on the renewal and maintenance of structural elements.

\begin{tabular}{|c|c|c|c|}
\hline \multirow[b]{2}{*}{ Bakım İle ilgili Sorular } & \multirow[b]{2}{*}{ Seçenekler } & \multicolumn{2}{|c|}{ İşletme Sayıs1 } \\
\hline & & Adet & Yüzde (\%) \\
\hline \multirow{4}{*}{$\begin{array}{l}\text { Plastik örtü malzemesinin yenilenme } \\
\text { süresi (yıl) }\end{array}$} & 1 & - & - \\
\hline & 2 & 5 & 12 \\
\hline & 3 & 32 & 76 \\
\hline & $3<$ & 5 & 12 \\
\hline \multirow{4}{*}{$\begin{array}{l}\text { Cam örtü malzemesinin bakım sıklığ } 1 \\
\qquad(\mathrm{y} 1 \mathrm{l})\end{array}$} & 1 & - & - \\
\hline & 2 & 3 & 27 \\
\hline & 3 & 2 & 18 \\
\hline & $3<$ & 6 & 55 \\
\hline \multirow{4}{*}{$\begin{array}{l}\text { Sera örtü malzemesinin temizlenme } \\
\text { şekli }\end{array}$} & Basınçlı su ile yıkıyorum. & 15 & 30 \\
\hline & Sera üstü spring sistemi ile yıkıyorum. & - & - \\
\hline & Temizlenmesi için yağmurların yağmasını bekliyorum. & 35 & 70 \\
\hline & Diğer & - & - \\
\hline
\end{tabular}

\section{Sonuç}

Antalya ili Demre ilçesinde incelenen seraların yapısal özellikleri işletme sahipleriyle yüz yüze yapılan anketler sonucunda ortaya konulmuştur. İşletme sahiplerinin \%72'sinin 15 yıldan fazla deneyim sahibi olduğu göz önüne alınarak çoğunluğunun ilkokul mezunu olduğu ve seralarını uzman kişilerden yardım almadan projesiz bir şekilde inşa edildiği belirlenmiştir. Geleneksel olarak inşa edilen seraların ileriye yönelik düşünüldüğünde yapısal sorunların oluşacağı ve verimin düşebileceği göz önüne alınarak tedbirlerin alınması önemlidir.

İncelenen seraların tamamı aile işletmesi olarak işletilmektedir. Yetiştirilen ürünler çoğunlukla yurt dışına olmak üzerek yurt içine de ürün pazarlanarak hem bölgesel hem ulusal ekonomik katkı sağlanmaktadır.

İncelenen seralarda boyutsal özellikleri ortalama olarak genişlik $23.7 \mathrm{~m}$, uzunluk $64.8 \mathrm{~m}$, yükseklik $3.6 \mathrm{~m}$ ve yan duvar yüksekliği 2.3 m'dir. Genel olarak tekil seraların boyutları literatürdeki optimum değerler ile karşılaştırılınca uzunluk ve yükseklik değerlerinin normal değerler ile örtüşürken genişlik boyutları literatürdeki değerlerin üzerinde gözlemlenmiştir. Bu durum seraların 1sıtması için tüketilecek olan dizel yakıtı artıracak ve dolayısıyla enerji maliyetleri de artmış olacaktır.

Antalya'nın ikliminden dolayı sera örtü malzemesi olarak plastik, yaygın olarak kullanılmaktadır. Plastik materyali içerisinden ise işletmelerin \%90'ının UV(ultraviolet) + IR(infrared) + EVA(Ethylene Vinyl Acetate) katkılı polietilen malzemesi kullandığı belirlenmiştir. Seralarda kullanılan iskelet sistemi incelendiğinde, tamamında çelik profil kullanılırken seraların \%64'ü sera, \%36'sı ise yüksek tünel şeklinde işletilmektedir. İncelenen seralarda kullanılan örtü malzemeleri, bölgenin iklim özelliklerine uyumludur ve IR katkısı olması güneşin olumsuz etkilerine karşı plastik örtü malzemesini koruyarak uzun süre kullanımına olanak sağlayacaktır.

İncelenen seralarda kullanılan aşık, mertekler, kap1 ve pencereler ile havalandırma açılarında kullanılan yapı malzemesi ve boyutlar genel anlamda literatürde seralar için önerilen özellikleri karşılamaktadır. Ancak havalandırma açıklıklarının açılması ve kapanması işlemlerinde manuel işletimden ise otomasyon ile işletilmesi iç ortamdaki temiz hava ve $\mathrm{CO}_{2}$ miktarı için oldukça önem taşımaktadır.

Demre ilçesinde incelenen plastik örtü materyalini kullanan seraların \%76'sı örtü materyallerini 3 yılda yenilemektedir.
Plastiklerin ömürler 6 ay ile 3 yıl arasında değiştiğinden dolayı yenileme süreleri idealdir. Cam örtü malzemesi kullanan seraların \%55'inde ise bakımlarının 3 yıldan fazla süre aralıklarla yapıldığı gözlemlenmiştir. Sera işletme sahipleri ekonomik olması ve iş gücü gerekmediğinden dolayı genel olarak seralarının yıkanması için yağmurun yağmasını beklemektedir.

Sonuç olarak, seracılık faaliyetlerinden beklenen ekonomik kazanımları sağlayabilmek için planlamadan, projeleme ve inşasına kadar olan tüm aşamalarında geleneksel inşa yaklaşımından vazgeçilmesi ve konuyla ilgili eğitim almış uzmanların görüşleri doğrultusunda inşa edilmesi gerekir. Ancak bu yol ile ekonomik olarak rakip ülkelerle rekabet edebilecek ürün verimi ve karlılık oranını yakalayabiliriz.

\section{Kaynaklar}

Arıcı İ (2003) Sera Yapım Tekniği. IV. Baskı, Uludağ Üniversitesi Ziraat Fakültesi Ders Notları, Bursa.

Atılgan A, Oz H, Yilmaz, HI, Uzer H (2014) Determination of current status in the resulting of waste materials from production of greenhouse and its environmental interaction. 13th International Scientific Conference Engineering for Rural Development Proceedings. Jelgava, Latvia. Volume 13, s. 120-125.

Baytorun AN (2016) Seralar, Sera Tipleri, Donanım ve İklimlendirilmesi. 1.Baskı, Nobel Akademik Yayıncılık Eğitim ve Danışmanlık Tic. Ltd. Şti., Ankara.

Boyacı S (2018) Kırşehir ilindeki sera ve yüksek tünellerin mevcut durumu üzerine bir araştırma. Mediterranean Agricultural Sciences 31(2): 129-136.

Çanakcı M, Akıncı İ (2007) Antalya ili seralarında kullanılan havalandırma ve 1sitma sistemleri. Akdeniz Üniversitesi Ziraat Fakültesi Dergisi 20(2): 241-252.

Fenkli M (2012) Antalya yöresindeki seralarda dinamik dış yüklerden dolayı meydana gelen konstrüksiyon hasarlarının tespiti ve çözüm önerileri üzerine bir araştırma. Doktora Tezi, Süleyman Demirel Üniversitesi Fen Bilimleri Enstitüsü, Isparta.

Fenkli M, Filiz M (2013) Batı Akdeniz bölgesi sera yapılarının yapısal karakteristiklerinin incelenmesi. SDU International Journal of Technological Science 5(2): 114-121.

Google Haritalar (2019) Antalya Haritası. https://www.google.com/maps/place/Demre,+Antalya/@36.238852 $9,29.9166509,12.5 \mathrm{z} / \mathrm{data}=! 4 \mathrm{~m} 5 ! 3 \mathrm{~m} 4$ ! $1 \mathrm{~s} 0 \times 14 \mathrm{c} 1 \mathrm{f} 2125 \mathrm{~d} 67 \mathrm{bfbd}: 0 \times \mathrm{xda} 7$ c5f586d1b7586!8m2!3d36.244444!4d29.987479. Erişim 10 Şubat 2019. 
Gale U, Tüzel Y, Öztekin GB (2014) Antalya'nın Kepez ilçesinde geleneksel sera üretiminin özellikleri. Türkiye Tarımsal Araştırmalar Dergisi 1(1): 68-77.

Genç E (1981) Seralarımızda Isıtma, Havalandırma (Klima) Özellikleri ve Alınabilecek Tedbirler. I. Türkiye Seracıllk Kongresi, Antalya, s. $63-68$.

Genç Ö, Yüksel AN, Şişman CB, Gezer E (2010) Balıkesir koşullarında sera 1s1 gereksinimlerinin belirlenmesi. Bursa Uludağ Üniversitesi Ziraat Fakültesi Dergisi 24: 73-84.

Genç Ziraat (2019) Seralarda Kullanılan Yapı Malzemeleri ve Seralarda Yap1 Elemanları. http://www.gencziraat.com/seraplanlamasi/seralarda-kullanilan-yapi-malzemeleri-ve-seralardayapi-elemanlari.html. Erişim 12 Şubat 2019.

Güllüler F (2007) Adana ili ve ilçelerindeki seraların yapısal özelliklerinin incelenmesi ve T.S.E standartlarına uygunluğunun araştırılması. Yüksek lisans Tezi, Çukurova Üniversitesi Fen Bilimleri Enstitüsü, Adana.

Hakgören F, Kürklü A (2004) Sera Planlaması. Akdeniz Üniversitesi Ziraat Fakültesi, Antalya.

Kolay HŞ (2016) İstanbul ili sınırları içerisinde yer alan örtüaltı yetiştiriciliğin yapısal yönden incelenmesi. Yüksek Lisans Tezi, Namık Kemal Üniversitesi Fen Bilimleri Enstitüsü, Tekirdağ.

Olgun M (2016) Tarımsal Yapılar. 3. Baskı, Ankara Üniversitesi Yayınları, Ankara.

Öneş A (1986) Sera Yapım Tekniği. Ankara Üniversitesi Ziraat Fakültesi Yayınları, No: 970, Ankara.

Saltuk B (2005) Mersin ili ve ilçelerinde bulunan plastik seraların yapısal yönden incelenmesi ve geliştirilme olanakları üzerine bir araştırma. Yüksek Lisans Tezi, Çukurova Üniversitesi Fen Bilimleri Enstitüsü, Adana.

Saltuk B (2018) Current situation in Mediterranean greenhouses and a structural analysis example (Mersin province). Fresenius Environmental Bulletin 27(12B): 9954-9961.
Saltuk B, Aydın Y, Mikail N (2019) Siirt ve Antalya illeri için seraların 1S1 gereksiniminin belirlenmesi ve karşılaştırılması. Mediterranean Agricultural Sciences 32(1): 73-78.

Tarım ve Orman Bakanlığı (2019) Örtüaltı Yetiştiricilik https://www.tarimorman.gov.tr/Konular/Bitkisel-Uretim/Tarla-veBahce-Bitkileri/Ortu-Alti-Yetistiricilik. Erişim 13 Nisan 2020.

Topçuoğlu K (2013) Muğla yöresi yüksek tünel tipi örtüaltı yapısının statik analizi. Tarım Bilimleri Araştırma Dergisi 6 (2): 133-139.

TUiK (2019) Türkiye İstatistik Kurumu, Bitkisel Üretim İstatistikleri, Örtüaltı Üretimi, http://www.tuik.gov.tr. Erişim 13 Nisan 2020.

Türkay C, Öztürk HH, Pınar H, Hocagil MM (2006) Anamur yöresindeki muz seralarının yapısal ve işlevsel özellikleri. Alatarım Dergisi 5(2): 17-22.

TÜRKTOP (2012) Türkiye Tohumcular Birliği. http://www.turktob.org.tr. Erişim 25 Aralık 2019.

Tüzel Y, Öztekin GB, Karaman İ (2010) Serik ilçesindeki modern ve geleneksel sera işletmelerinin üretici özellikleri, sera yapısı ve sebze üretim teknikleri bakımından karşılaştırılması. Ege Üniversitesi Ziraat Fakültesi Dergisi 47(3): 223-230.

T.C. Demre Kaymakamlığ (2019). http://www.demre.gov.tr/tarim-vehayvancilik. Erişim 13 Şubat 2019.

Von Zabeltitz C (2011) Integrated Greenhouse Systems for Mild Climates. Crop Growth Requirements and Climate Control, Springer, Berlin, Heidelberg, pp. 30.

Yağanoğlu AV, Örüng İ (1997) Seracılıkta son gelişmeler ve sera tipleri. 2. Serac1lık Sempozyumu, 31 Mayıs-01 Haziran, Kütahya.

Yağanoğlu V (2013) Örtüaltı yapıları. Atatürk Üniversitesi Ziraat Fakültesi Yayınları, Erzurum.

Yüksel AN (2000) Sera Yapım Tekniği. Hasad Yayıncılık Dağıtım, İstanbul.

Yüksel AN, Yüksel E (2012) Sera Yapım Tekniği. 5. Baskı, Hasad Yayıncılık Dağıtım, İstanbul. 